\title{
Analisis Promosi Goffee Indonesia Di Instagram
}

\author{
Melly Dermawan, Yugih Setyanto, Sisca Aulia \\ mellydarmawan5@gmail.com,yugihs@fikom.untar.ac.id, siscaa@fikom.untar.ac.id
}

Fakultas Ilmu Komunikasi Universitas Tarumanagara

\begin{abstract}
:
Along with the development of coffee shops in Indonesia added to the author's interest to want to know more about the coffee shop business, one of which is Goffee Indonesia. Goffee Indonesia is a coffee shop located in the Special Capital Region of Jakarta, namely at ITC Mangga Dua Lantai 2. Marketing Communication is a means of informing, persuading and reminding customers directly or indirectly about a product or service offered (Kotler 2009: 172). In general, marketing communication represents the "voice" of the company and its brand and is a suggestion that the company can create dialogue and build relationships with consumers (Kotler, 2009: 172). The purpose of this study was made to find out more in the analysis of promotions carried out by Goffee Indonesia on Instagram. Then this study uses qualitative research methods through ethnographic approaches. The study used interview methods with 6 informants consisting of coffee shop owners, admin Goffee Indonesia Instagram accounts, and also customers. From the research obtained from sources, interviews, observations and ethnographic studies. In order for effective marketing or promotional communications by Goffee Indonesia, Goffee Indonesia also always makes attractive promotions every day, and having a desire will add to the growing interest in buying consumers. And from the results of this study, Instagram is very useful in marketing communications or promotions carried out by Goffee Indonesia.
\end{abstract}

\begin{abstract}
Abstrak:
Seiring berkembangnya kedai kopi di Indonesia menambah minat penulis untuk ingin mengetahui lebih dalam tentang bisnis kedai kopi tersebut, yang salah satunya adalah Goffee Indonesia. Goffee Indonesia merupakan kedai kopi yang berlokasi di Daerah Khusus Ibukota Jakarta, yaitu di ITC Mangga Dua lantai 2. Komunikasi Pemasaran merupakan suatu sarana menginformasikan, membujuk serta mengingatkan pelanggan secara langsung maupun tidak langsung tentang suatu produk atau jasa yang ditawarkan (Kotler 2009:172) . Pada umumnya, komunikasi pemasaran merepresentasikan "suara" perusahaan dan mereknya serta merupakan saran dimana perusahaan dapat membuat dialog dan membangun hubungan dengan konsumen (Kotler, 2009:172). Tujuan penelitian ini dibuat adalah untuk mengetahui lebih dalam analisis promosi yang dilakukan Goffee Indonesia di Instagram. Kemudian penelitian ini menggunakan metode penelitian kualitatif dengan melalui pendekatan etnografi. Penelitian menggunakan metode wawancara dengan 6 informan yang terdiri dari pemilik kedai kopi, admin akun instagram Goffee Indonesia, dan juga pelanggan. Dari penelitian yang diperoleh bersumber dari wawancara, observasi dan studi etnografi. Agar komunikasi pemasaran atau promosi yang dilakukan Goffee Indonesia berjalan dengan efektif, Goffee Indonesia juga selalu membuat promosi yang menarik setiap hari, dan memiliki keinginan akan menambah semakin banyak minat beli konsumen. Dan dari hasil penelitian ini adalah Instagram sangat bermanfaat dalam komunikasi pemasaran ataupun promosi yang dilakukan Goffee Indonesia.
\end{abstract}

Kata kunci: Komunikasi Pemasaran, Instagram, Promosi, Goffee Indonesia. 


\section{Pendahuluan}

Seiring berkembangnya zaman teknologi kini makin melesat, seperti sekarang ini, salah satu cara komunikasi untuk melakukan promosi agar penjual dengan pembeli dapat dengan cepat dan mudah melakukan transaksi sehingga menghemat waktu dan tenaga sehingga tidak perlu datang ke lokasi yaitu ialah melalui media sosial. Dalam hal melakukan promosi, kini media sosial adalah salah satu media yang cukup efektif karena memiliki jangkauan yang cukup luas.

Pada saat ini, hampir semua penjual mulai dari perusahaan besar, perusahaan kecil, hingga toko- toko kecil menggunakan Instagram sebagai salah satu strategi untuk memasarkan atau mempromosikan barang atau jasa yang ingin dijual. Cukup banyak yang menggunakan media sosial Instagram sebagai media untuk promosi karena efektif, terjangkau serta mencakup wawasan yang luas dan juga dapat di akses dengan mudah dimana saja dan kapan saja serta anak muda hingga orang tua sekalipun. Sehingga dengan banyaknya pengguna Instagram dapat memberikan keuntungan yang besar untuk pemilik usaha.

Media sosial sekarang merupakan media yang sangat dibutuhkan dan sangat berpengaruh bagi para pengusaha untuk melakukan penjualan dengan mudah karena memudahkan penjual dan pembeli dalam melakukan transaksi jual beli, yaitu dari segi lokasi dan waktu. Kelebihan lainnya adalah media sosial Instagram memiliki jangkauan yang luas dan juga memiliki sistem promosi di dalam aplikasinya sehingga menambah kemudahan untuk berpromosi contohnya Instagram dapat melakukan promosi dengan harga yang terjangkau sesuai budget, lalu dapat memilih segmentasi pasar atau target yang ingin dituju serta seberapa luas jangkauan yang kita inginkan.

Instagram merupakan aplikasi media sosial untuk mengupload beberapa foto atau video, Instagram pun dapat di gunakan untuk sarana promosi barang dan jasa. Maka dapat diartikan internet merupakan media yang sangat berpotensi besar saat ini karena dapat digunakan untuk melakukan promosi. Promosi menggunakan Instagram juga sangat terjangkau.

Komunikasi pemasaran merupakan cara untuk membujuk, menginformasikan dan mengingatkan pelanggan secara langsung maupun tidak langsung mengenai produk atau jasa yang dijual. Komunikasi pemasaran bertujuan membangun hubungan dengan konsumen. Ada 4 (4P) unsur bauran pemasaran yaitu:

1. Product

Goffee Indonesia menyediakan minuman kopi, yang artinya masuk kedalam kategori barang tidak tahan lama. Menurut wawancara penulis dengan salah satu konsumen Goffee Indonesia yang bernama Valen, ia mengatakan bahwa produk atau kopi yang dijual di Goffee Indonesia cukup menarik dan bervariatif.

2. Price

Goffee Indonesia menawarkan minuman dengan harga standar yaitu mulai dari dua puluh ribu hingga tiga puluh lima ribu rupiah. Berdasarkan hasil wawancara dengan salah satu pelanggan Goffee, dikatakan bahwa harga yang di berikan tidak terlalu mahal.

3. Place

Tempat yang dipilih oleh Goffee Indonesia menurut hasil wawancara dengan pemilik, bahwa lokasi yang dipilih adalah lokasi yang menjadi trademark di ITC Mangga Dua, sehingga menjadi nilah tambah Goffee Indonesia, namum 
juga ada kekurangan dari segi lokasi, yaitu ojek online yang cukup sering membatalkan orderan karena merasa sulit berkeliling di ITC Mangga Dua yang cukup ramai dan padat.

4. Promotion

Goffee Indonesia selalu memberikan promosi yang berbeda setiap harinya guna untuk meningkatkan jumlah penjualan agar konsumen merasa senang karena adanya promo yang berbeda- beda setiap harinya.

American Marketing Association mengatakan pemasaran merupakan proses dan kebutuhan organisasi dalam menciptakan komunikasi dengan pelanggan dan menjalin hubungan dengan konsumen dengan saling menguntungkan (Kotler 2009).

\section{Metode Penelitian}

Penulis menggunakan metode penelitian kualitatif dan dengan pendekatan penelitian etnografi. Penelitian kualitatif menurut Sugiono adalah cara ilmiah untuk menemukan data yang valid dengan memiliki tujuan yang dapat ditemukan, dibuktikan dan dikembangkan oleh pengetahuan tersendiri kemudian pada gilirannya dapat digunakan untuk memahami, memecahkan, serta menghindari masalahmasalah yang dapat terjadi dalam bidang pendidikan (Sugiyono, 2011:6). Kemudian Etnografi sendiri merupakan suatu metodelogi dengan cara pengamatan secara langsung dengan melihat, kemudian mengamatin dan selanjutnya meneliti (Bungin,2010).

Selanjutnya penulis melakukan pengamatan dan melihat langsung ke kedai kopi Goffee Indonesia sehingga penulis mampu mengenal lebih dekat dan mengetahui lebih banyak seluruh data- data yang perlukan. Serta melalui penelitian ini, penulis menggunakan metode kualitatif untuk memenuhi data- data yang dibutuhkan, dan untuk menjalankan metode penelitian kualitatif maka penulis juga melakukan wawancara serta observasi untuk memenuhi kebutuhan yang ingin penulis teliti.

Penelitian yang dilakukan penulis dengan mewawancarai pemilik Goffee Indonesia yaitu Erwin dan Darwis, kemudian penulis juga mewawancarai pemegang akun Instagram Goffee Indonesia, serta yang terakhir untuk melengkapi hasil wawancara penulis, penulis juga melakukan wawancara terhadap konsumen Goffee Indonesia. Sehingga penulis mendapatkan enam narasumber untuk melengkapi penelitian penulis.

\section{Hasil Temuan dan Diskusi}

Dari wawancara penulis dengan Darwis salah satu pemilik Goffee Indonesia, Darwis menjelaskan awal mula pemilihan nama merk dan juga logo Goffee Indonesia, merk yang dipilih awalnya berasal dari grab your coffee yang kemudian di singkat menjadi Goffee, dan gambar anjing yang dipilih oleh Goffee sebagai logo yaitu di ceritakan oleh Darwis bahwa pada saat awal mula kedua pemilik mulai belajar mengenai kopi itu di tahun anjing, maka mereka sepakat untuk memilih gambar anjing sebagai logo Goffee Indonesia.

Goffee Indonesia yang terletak di Mall ITC Mangga Dua ini memiliki waktu operational yaitu mulai pukul 09.00- 18.00 WIB. Menu yang di tawarkan oleh Goffee Indonesia juga sangat beragam dan bervariatif, kurang lebih 23 menu yang 
disajikan. Selain menyajikan kopi siap minum, Goffee Indonesia juga menyediakan beberapa makanan kecil seperti kentang goreng, roti goreng, hingga biji kopi kemasan. Lokasi yang dipilih Goffee Indonesia juga cukup ramai pengunjungnya.

Lalu yang di utamakan di kedai kopi ini adalah yang pertama Goffee Indonesia lebih memprioritaskan mutu kualitas kopinya dan juga selalu rutin dilakukan pengecekan oleh pemilik agar kopi yang di sajikan dapat sesuai dengan standar. Goffee Indonesia juga memiliki visi ingin selalu dan senantiasa memberikan kopi berkualitas tinggi dengan harga yang bersahabat. Kemudian dengan adanya visi tersebut, pekerja di Goffee Indonesia juga perlu mengutamakan memberikan pelayanan yang terbaik kepada para pelanggan. Goffee Indonesia juga memiliki visi ingin lebih banyak membuka cabang hingga ke luar negara. Goffee Indonesia juga memegang Misi untuk memberikan kopi terbaik sehingga menjadi kopi nomor satu di hati konsumen yang memiliki berbagai varian rasa yang menarik dan menjaga selalu kebersihan serta kenyamanan untuk pelanggan.

Goffee Indonesia juga belum pernah mengikuti kegiatan event- event ataupun pameran kopi karena Goffee sendiri belum lama berdiri, namun menurut pemilik Goffee Indonesia, walaupun Goffee belum pernah mengikuti kegiatan event maupun pameran akan tetapi Goffee selalu meningkatkan kegiatan promosi yang lebih giat, agar mampu bersaing dengan kedai kopi lain yang sudah lebih lama muncul. Karena banyaknya persaingan di dunia kopi maka sangat diperlukan semangat untuk melakukan promosi yang cukup tinggi.

Promosi atau komunikasi pemasaran yang dilakukan Goffee Indonesiapun melalui 5 langkah yaitu:

1. Iklan (Advertising)

Iklan yang dilakukan oleh Goffee salah satunya dengan menggunakan fitur dari Instagram yaitu Instagram Ads. Instagram Ads adalah fitur berbayar untuk mengiklankan suatu produk atau jasa di Instagram agar dapat dilihat oleh pengguna Instagram lainnya dengan jangkauan yang luas.

\section{Sales Promotion}

Sales Promotion yang dilakukan Goffee adalah dengan memberikan promo setiap harinya dengan berbeda- beda.

3. Penjualan Pribadi (Personal Selling)

Disini yang dilakukan Goffee dalam penjualan pribadi yaitu pelayan Goffee Indonesia membantu menjelaskan produk mana yang paling banyak diinginkan atau disukai oleh para konsumen untuk membantu pembeli memilih pesanannya.

\section{Direct Marketing}

Dengan merespons konsumen lewat kolom komentar Instagram maupun Direct message instagram, maka Goffee Indonesia telah melakukan Direct Marketing, karena admin Instagram Goffee selalu membalas ataupun merespons pertanyaan yang diajukan oleh khayalak seputar produk Goffee Indonesia,

\section{Word Of Mouth}

Dari hasil wawancara penulis dengan salah satu pelanggan Goffee Indonesia, dikatakan bahwa ia mengetahui Goffee sendiri dari salah satu temannya yang telah mencoba produk yang dijual oleh Goffee. 
Seiring berjalannya kedai kopi Goffee Indonesia setelah kurang lebih enam bulan, kabar baik pun datang menghampiri karena Goffee Indonesia akan segera membuka cabang kedai kopi nya di beberapa lokasi lagi, yaitu Mall Central Park dan Mall Ambasador. Karena banyaknya penikmat Goffee, sehingga Goffee Indonesia dapat melebarkan sayapnya sedikit demi sedikit.

Darwis yang adalah salah satu pemilik Goffee Indonesia mengungkapkan bahwa sangat diperlukannya promosi untuk menunjang peningkatan penjualan, karena saat ini dengan adanya promosi berkala melalui media sosial Instagram memberikan efek positif yang sangat menguntungkan yaitu selain meningkatnya nama merk produk, yang kedua juga dapat menambah omset penjualan Goffee Indonesia.

Dalam buku Komunikasi Pemasaran Kontekstual menurut Suwatno (2017:60) ada 3 konsep penting yaitu

1. Segmentasi Pasar

Goffee Indonesia memiliki segmentasi pasar menengah ke atas, karena Goffee sendiri menggunakan mesin- mesin berkualitas internasional di kedai kopinya.

2. Target Pasar

Goffee sendiri memiliki target utama dalam melakukan pemasaran, salah satunya karena Goffee berada di daerah yang sekelilingnya menjual makanan- makana yang banyak diminati warga, maka terget dari Goffee yang pertama adalah warga yang berada disana, salah satunya pengunjung, pecinta kopi, hingga pegawai kantor maupub mahasiswa yang memesan lewat applikasi.

3. Positioning

Goffee Indonesia memposisikan kedai kopinya sebagai kedai kopi yang menyediakan kopi dengan kualitas tinggi untuk kemudian dinikmati oleh para konsumennya.

\section{Simpulan}

Penulis melakukan penelitian dan mengambil kesimpulan seperti berikut:

1. Media sosial yang digunakan oleh Goffee Indonesia dalam melakukan komunikasi pemasarannya adalah dengan memakai aplikasi Instagram contohnya seperti Instagram Ads, food blogger, dan juga influencer karena dari hasil yang didapatkan dari narasumber mengatakan bahwa Instagram merupakan salah satu media sosial yang memiliki jangkauan cukup luas dan banyak diakses oleh seluruh kalangan.

2. Goffee Indonesia mempunyai target pasar untuk kalangan menengah ke atas karena kopi atau biji kopi yang di sajikan dapat dikatakan memiliki kualitas tinggi dan menggunakan mesin pembuat kopi berstandart internasional.

3. Promosi maupun pemasaran dalam kedai Goffee Indonesia sangat mengandalkan media sosial Instagram dalam meningkatkan penjualannya dan menciptakan brand awareness kepada konsumennya.

4. Promosi selalu dilakukan oleh Gofee Indonesia sebagai bauran untuk pemasarannya. Dan juga memberikan promo yang berbeda beda setiap harinya kepada pelanggannya. 
5. Semua karyawan Goffee Indonesia memiliki prinsip yaitu berbagi pengalaman terhadap semua rekannya terutama yang terpenting adalah kepada semua pelanggannya.

\section{Ucapan Terima Kasih}

Terima kasih yang sebesar- besarnya penulis panjatkan kepada Tuhan Yang Maha Esa serta Bapak Yugih Setyanto S.Sos.,M.Si yang berperan penting sebagai dosen pembimbing dan juga Ibu Sisca Aulia, S.I.Kom.,M.Si selaku co pembimbing yang sangat pengertian serta sangat sabar untuk selalu membimbing penulis dari awal pembuatan skripsi hingga selesainya penelitian ini. Penulis juga ingin mengucapkan terima kasih yang sebesar-besarnya kepada seluruh anggota besar Goffee Indonesia yang mengijinkan penulis dan bersedia untuk dilakukan penelitian produknyadan juga meluangkan waktunya di tengah- tengah kesibukan untuk di wawancarai dengan memberikan informasi kepada penulis untuk menyelesaikan penelitian ini, serta untuk semua yang terlibat membantu penulis dalam melakukan peneliti

\section{Daftar Pustaka}

Bungin, Burhan. 2010. Penelitian Kualitatif. Jakarta: Kencana.

Kotler, Philip. 2009. Manajemen Pemasaran. Jakarta: Penerbit Erlangga.

McQuail, Denis. 2011. Teori Komunikasi Massa McQuail, Edisi 6 Buku 1. Jakarta: Salemba Humanika

Moleong, Lexy J. 2011. Metode Penelitian Kualitatif. Bandung: PT. Remaja Rosdakarya.

Nasrullah, Rulli. 2017. Media Sosial : Perspektif Komunikasi, Budaya, dan Sosioteknologi. Bandung:Remaja Rosdakarya.

Sugiyono. 2016. Metode Penelitian Kualitatif. Bandung: Alfabeta.

Suwatno, H. (2017), Komunikasi Pemasaran Kontekstual. Bandung:

PT. Remaja Rosdakarya.

https://www.hinet.co.id/media-sosial-yang-terbanyak-diakses-orang-indonesiasiapa-nomor-1/)

https://www.republika.co.id/berita/ekonomi/makro/17/10/01/ox4r5w396-wowindonesia-produsen-kopi-terbesar-keempat-di-dunia (http://academia.edu/3326757/Marginalized_dan_Pertarungan_New_Media_vs_ Media_Cetak_)

http://www.tempo.co/read/news/2014/06/30/092589168/Orang-Indonesia-MakinGemar-Minum-Kopi

https://manual.co.id/article/manual-jakartas-debut-print-issue-jakarta-coffeemanual-jcm-2017/ 